\title{
ASSESSMENT OF THE DOSE TO THE HEART AND THE LEFT ANTERIOR DESCENDING CORONARY ARTERY FOR THE LEFT BREAST RADIOTHERAPY
}

\author{
Aista Plieskiené ${ }^{1,2}$, Dainius Burdulis ${ }^{2}$ \\ ${ }^{1}$ Klaipeda University Faculty of Health Sciences, Klaipeda, Lithuania, \\ ${ }^{2}$ Klaipèda University Hospital, Klaipeda, Lithuania
}

Key words: left breast radiotherapy, heart, LAD.

\section{Summary}

Radiotherapy for left breast cancer may increase risk of cardiovascular diseases. Exposing the anterior portion of the heart and left anterior descending coronary artery (LAD) to the highest radiation dose depends on individual anatomical location of these structures.

The purpose of this work was to assess the radiation doses delivered to the heart and the LAD for the left sided breast cancer patients treated with 3D conformal radiotherapy.

Thirty two randomly selected patients referred for adjuvant radiotherapy after conservation surgery for left sided breast cancer were evaluated. The whole heart, the arch of the LAD (LAD $\left.{ }^{\text {arch }}\right)$ and the whole LAD were contoured. The radiation doses $\left(\mathrm{D}^{\max }\right.$, $\mathrm{D}^{\text {mean }}$ ) to these three anatomical cardiac structures were evaluated.

For all 32 patients, the assessed radiotherapy plans were acceptable based on the dose constraints to critical structures: heart, $\mathrm{LAD}^{\text {arch }}$. The average mean doses $\left(\mathrm{D}^{\text {mean }}\right)$ to the heart are well below 5 Gy and 7,3 (range, 3,82 - 17,15 Gy) for the LAD ${ }^{\text {arch }}$ respectively. For $21,9 \%$ of patients, the $\mathrm{D}^{\text {mean }}$ to the heart and dose to the $\mathrm{LAD}^{\text {arch }}$ was relatively low while the $\mathrm{D}^{\text {mean }}$ to the whole LAD was considerably higher. Conclusion. Evaluation of the mean dose to the heart only could lead to excessive heart irradiation. The results of the study indicate that it is necessary to assess the dose delivered to the whole heart as well as to the whole LAD for evaluation of the left breast irradiation treatment plan. This is very important to minimise the risk of clinically significant cardiac events after left breast radiotherapy.

\section{Introduction}

After breast-conserving surgery, radiotherapy reduces recurrence and breast cancer death, but it may do so more for some groups of women than for others $(1,2)$. The researchers describe the absolute magnitude of these reductions according to various prognostic and other patient characteristics, and relate the absolute reduction in 15-year risk of breast cancer death to the absolute reduction in 10-year recurrence risk (1). However, this treatment for patients with left-sided cancer implies irradiating some of the ipsilateral lung and the heart, leading to the risk of long-term pulmonary and cardiac complications $(2,3,4)$. Today there is general awareness of the potential damage to the heart in left-sided (more than in right-sided) breast cancer radiotherapy. Historical changes in tumor and heart doses are presented with the impact of different RT techniques and volumes (5). Cardiac morbidity and mortality after breast cancer treatment is still relevant (2). Different strategies with the help of advanced imaging and treatment techniques to minimize radiation dose to the heart and the risk of side effects are being developed. The newest techniques include breathing-adapted radiotherapy. The deep inspiration breath-hold technique which takes more time than conventional method is not routinely used in Lithuania. Researchers request for further investigation that should be aimed at clarifying optimum staff training, patient-selection is required to determine optimum protocols for patient training and treatment verification to ensure the technique is delivered successfully and efficiently uses resources of the health care system (6). However, modern computer tomography (CT) based three-dimensional (3D) conformal treatments are adequate for many of clinical left breast cancer radiotherapy cases thought to have reduced the risk of heart damage $(2,7)$. At present, in a busy clinic environment, the most important is to optimise the modern CT-based 3D conformal treatment planning reassessing dose constraints 
of the organs at risk.

The aim of this study: to determine optimal criteria's for organs at risk delineation in left breast cancer radiotherapy.

\section{Methods and materials}

Thirty two randomly selected patients referred for adjuvant radiotherapy after breast-conserving surgery for leftsided breast cancer in 2014-2016: all women, age ranging from 36 to 85 years, median 59 years, at the time of treatment. The radiotherapy target volume typically encompasses the remaining breast tissue after resection of the tumor and, in cases with lymph node metastases, also the regional lymph node areas. Prescribed total radiation dose to the planning target volume (PTV) was 50 Gy in 25 daily fractions ( 5 fractions a week; delivered in 5 weeks).

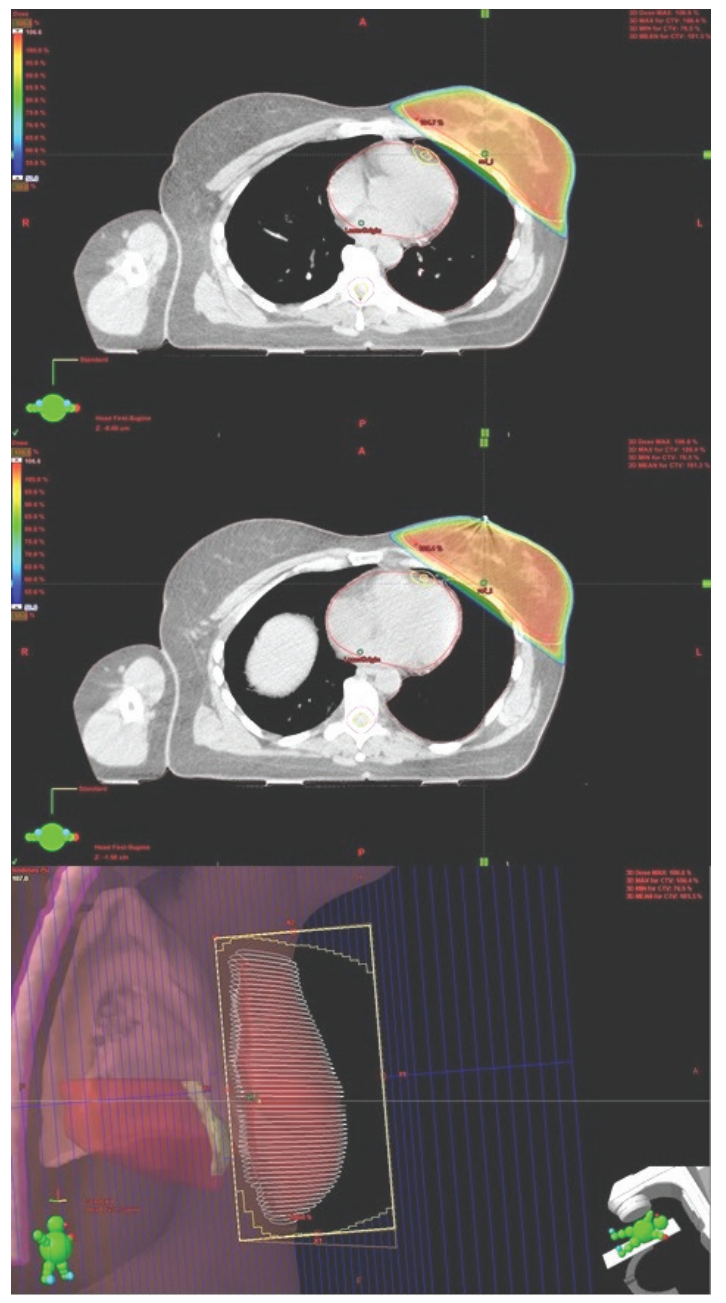

Figure 1. CT based breast radiation treatment plan
Dose volume histograms (DVH) for the radiotherapy patients breast irradiation plans were evaluated. The doses delivered to heart, $\mathrm{LAD}^{\text {arch }}$ and whole $\mathrm{LAD}$ are assessed. The PTV should be covered by $90-107 \%$ of the prescription dose (50 Gy).

CT images from the 32 patients are exported to a treatment planning system (Eclipse, Varian Medical Systems). In our radiotherapy centre, the whole heart and arch of the LAD is routinely contoured by the radiation oncologist and is used for evaluation of dose to the organs at risk according to the recommendations $(8,9)$. Additionally, in this study the radiation oncologists were recruited to delineate the whole left anterior descending interventricular branch $\mathrm{LAD}$ in the CT volume (8).

The dose to the $5 \%$ and $10 \%$ of heart volume and average mean heart dose were evaluated. The $\mathrm{D}^{\text {max }}$, $\mathrm{D}^{\text {mean }}$ and $\mathrm{V}^{20}$ ( $10 \%$ of the contoured volume received $20 \mathrm{~Gy}$ ) of LAD in comparison with $\mathrm{LAD}^{\text {arch }}$ were assessed.

The $6 \mathrm{MV}$ classical techniques with tangents and individual segments (subfields) using photon beams were used to cover the breast (Figure 1). The dose uniformity throughout the target volume and the shielding of organs at risk were achieved using wedges and multileaf collimators. DVH were introduced as a tool for plan evaluation, in which the cumulative doses to the organ volumes are graphed. Figure 2 shows an example of a DVH graph for 3D conformal radiotherapy plan.

The acceptability of the radiotherapy plans in this study is then analysed assessing the dose delivered to the whole heart, the LAD arch and the whole LAD. The whole LAD is considered to be receiving a high dose when over $10 \%$ of the contoured volume received 20 Gy or more.

\section{Results and discussion}

Exposure of the heart to ionizing radiation during radiation therapy for the breast cancerincreases the subsequentrate

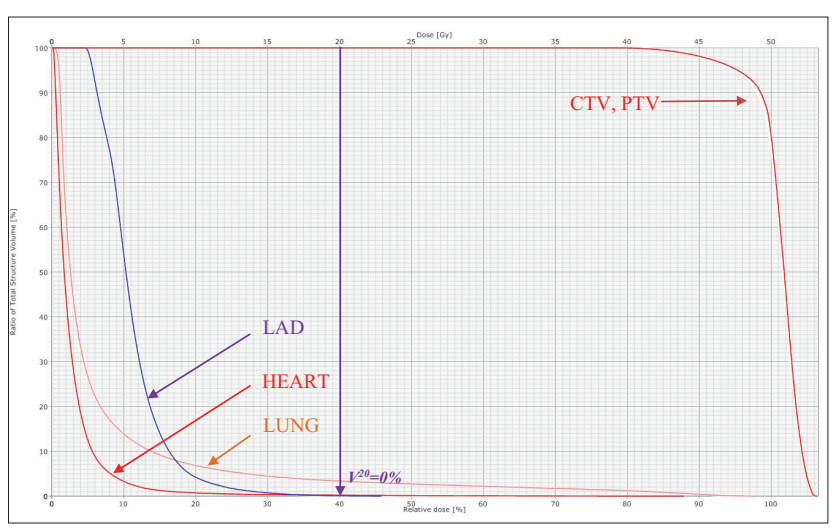

Figure 2. DVH for left sided breast cancer radiotherapy plan 


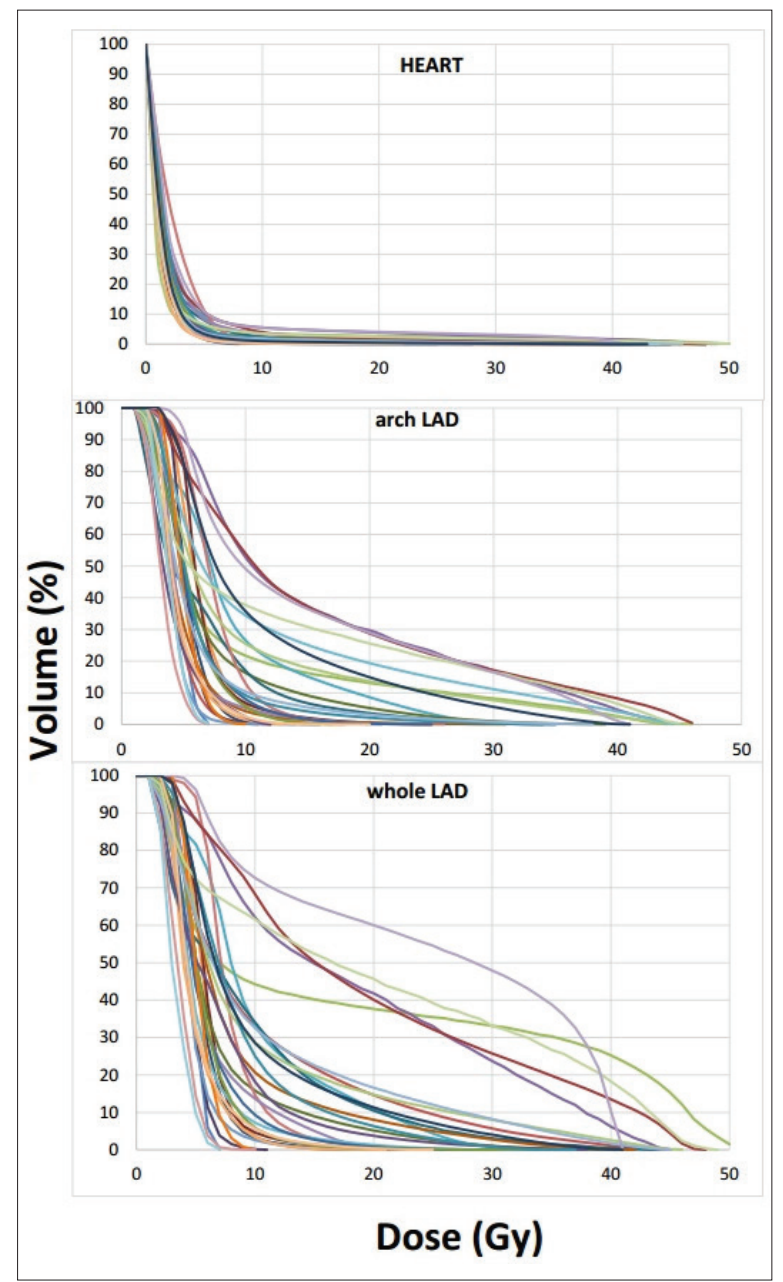

Figure 3. DVH for all patients for the heart, $\mathrm{LAD}^{\text {arch, }}$, and the whole LAD

of ischaemic heart disease caused by coronary stenosis (10).

A relationship can generally be established between the volume of a healthy organ receiving high radiation doses and the probability of side effects $(2,7)$. Patients with leftsided cancer had a higher risk of cardiac mortality than patients with right-sided cancer (11).

It has been suggested that if 5\% of the heart receives $40 \mathrm{~Gy}$, the risk of cardiac mortality exceeds $2 \%$ (12). Consequently, in the adjuvant setting it is pivotal to minimise radiation to the heart since breast cancer survivors have a good prognosis for cancer-free survival and may live several decades after treatment (2).

The results of the study are presented in Figure 3. For all 32 patients, the plans are acceptable based on the criteria for whole heart and $\mathrm{LAD}^{\text {arch }}$. The average mean doses to the heart are well below 5 Gy and 7,3 (range, 3,82-17,15) for

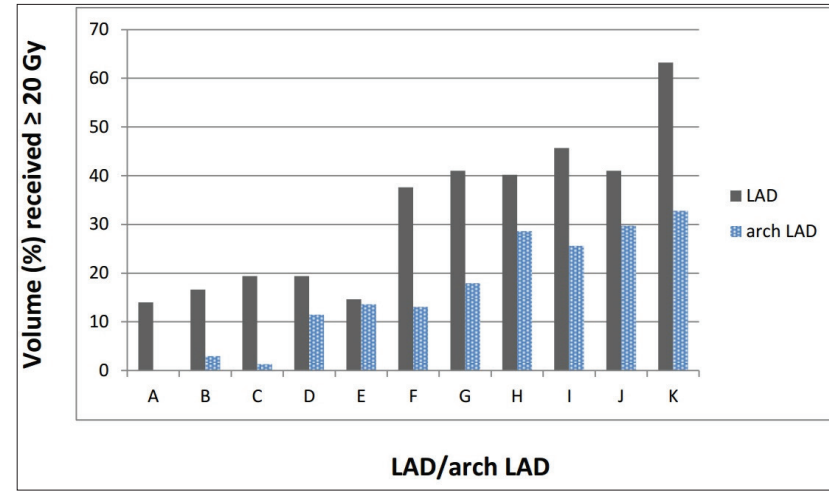

Figure 4. Selected cases with significant dose to the LAD, $\mathrm{LAD}^{\text {arch }}$ : the volume of the structure received $\geq 20 \mathrm{~Gy}$

the $\mathrm{LAD}^{\text {arch }}$ respectively. In $21,9 \%$ of patients, the dose to the $\mathrm{LAD}^{\text {arch }}$ was relatively low while the mean dose to the whole LAD was considerably higher.

Most important results shows, that for 11 patients the heart $\mathrm{D}^{\text {mean }}$ was only 2,15 (range, $1,37-3,98$ ), while a significant dose to the whole left anterior descending interventricular branch being delivered (Figure 4). Other authors published the results of study, which reported the cases, in which the dose to the LAD and LAD ${ }^{\text {arch }}$ was very low, but significant (but still within acceptability criteria) portion of the heart is included in the field (2). We found 4 such a cases (Figure 4: A,B,C,D). There were no cases where the dose to the LAD ${ }^{\text {arch }}$, LAD and whole heart dissociated. But in 7 cases the dose to the LAD ${ }^{\text {arch }}$ was relatively low, however the dose to the whole LAD was significantly higher (14,6-37,6\% of the contoured volume received over $20 \mathrm{~Gy})$ (Figure 4: E,F,G,H,I,J,K). Other researchers have found analogous results in 2011 (2). They illustrate the fact that the inferior portion of LAD receives the higher dose (2). Irradiation of this area is arguably less likely to lead to cardiovascular complications than irradiation of $\mathrm{LAD}^{\text {arch }}$, as it supplies a smaller part of myocardial tissue, but should still be considered at risk in view of the high doses $(2,5)$.

The results of this study showed that the mean doses to the three cardiac structures are 1,88 (range, 1,25-3,98 Gy) for the heart, 7.3 (range, 3,82-17,15 Gy) for the $\mathrm{LAD}^{\text {arch }}$ and 9,64 (range, 3,24-27,84 Gy) for the LAD.

Other studies have showed similar or higher $\mathrm{D}^{\text {mean }}$ to the heart $(2,12)$. And the $\mathrm{D}^{\text {mean }}$ to the heart in this study was slightly higher than the lowest average mean heart doses from tangential radiation therapy with either breathing control (1.3 Gy; range, 0.4-2.5 Gy) (12). The $\mathrm{D}^{\text {mean }}$ to the whole LAD was also lower as published in the literature $(2,13)$. These differences could be caused by changing of 
treatment techniques or contouring strategy (2).

In the Figure 3 we can distinguish the group of patient where the whole LAD receives up to 40 Gy to a significant volume of this vessel. It would be valuable to see how much the dose to the LAD can be reduced in this group by optimization of the treatment planning or using new techniques in radiotherapy with this dose as an evaluation criterion (2).

The results show that is difficult to find the optimal one organ to assess the dose received by cardiac structures, but as we see the tendency that a very low dose to the LAD is associated with a very low dose to the heart, but in low dose to the whole heart we can define the highest doses to the LAD. In summary of these results we propose to delineate the whole LAD along with the whole heart as organ at risk, not only the $\mathrm{LAD}^{\text {arch }}$, for radiotherapy plan optimisation.

\section{Conclusion}

Evaluation of the mean dose to the heart only could lead to excessive heart irradiation.

The results of the study indicate that it is necessary to assess the dose delivered to the whole heart as well as to the whole LAD for evaluation of the left breast irradiation treatment plan. This is very important to minimise the risk of clinically significant cardiac events after left breast radiotherapy.

\section{References}

1. Effect of radiotherapy after breast-conserving surgery on 10year recurrence and 15-year breast cancer death: meta-analysis of individual patient data for 10801 women in 17 randomised trials. Lancet 2011;378(9804):1707-16.

http://dx.doi.org/10.1016/S0140-6736(11)61629-2

2. Aznar MC, Korreman S-S, Pedersen AN, Persson GF, Josipovic M, Specht L. Evaluation of dose to cardiac structures during breast irradiation. The British Journal of Radiology 2011;84 :743-46.

http://dx.doi.org/10.1259/bjr/12497075

3. Clarke M, Collins R, Darby S, Davies C, Elphinstone P, Evans $\mathrm{E}$, et al. Effects of radiotherapy and of differences in the extent of surgery for early breast cancer on local recurrence and 15year survival: an overview of the randomised trials. Lancet 2005;366:2087-106.

http://dx.doi.org/10.1016/S0140-6736(05)67887-7

4. EBCTCG (Early Breast Cancer Trialists' Collaborative Group). Effect of radiotherapy after mastectomy and axillary surgery on 10-year recurrence and 20-year breast cancer mortality: meta-analysis of individual patient data for 8135 women in 22 randomised trials. The Lancet 2014;383: 2127-35. http://dx.doi.org/10.1016/S0140-6736(14)60488-8

5. Petruzzelli AS, Fonte M, D'Errico MP, Grimaldi L, Pili G,
Portaluri M. Radiation-induced cardiac damage in early left breast cancer patients: Risk factors, biological mechanisms, radiobiology, and dosimetric constraints. Radiother \& oncol 2012;103(2):133-42.

http://dx.doi.org/10.1016/j.radonc.2012.02.008

6. Latty D, Stuart KE, Wang W, Ahern V. Review of deep inspiration breath-hold techniques for the treatment of breast cancer. J Med Radiat Sci 2015 Mar; 62(1):74-81.

http://dx.doi.org/10.1002/jmrs.96

7. Schultz-Hector S, Trott KR. Radiation-induced cardiovascular diseases: is the epidemiologic evidence compatible with the radiobiologic data? Int J Radiat Oncol Biol Phys 2007;67(1):10-8. http://dx.doi.org/10.1016/j.ijrobp.2006.08.071

8. Feng M, Moran JM, Koelling T, Chughtai A, Chan JL, Freedman L, Hayman JA, Jagsi R, et al. Development and validation of a heart atlas to study cardiac exposure to radiation following treatment for breast cancer. Int J Radiat Oncol Biol Phys 2011: 79(1): 10-18.

http://dx.doi.org/10.1016/j.ijrobp.2009.10.058

9. Dellas K, Vonthein R, Zimmer J, Dinges S, Boicev AD, Andreas P, Fischer D, Winkler C, Ziegler A, Dunst J; ARO Study Group10.1007/s00066-014-0658-5. Epub 2014 Apr 16. Hypofractionation with simultaneous integrated boost for early breast cancer: results of the German multicenter phase II trial (ARO-2010-01). Strahlenther Onkol 2014;190(7):646-53.

http://dx.doi.org/10.1007/s00066-014-0658-5

10. Kato M, Kagami Y, Yoshimura R, Hamada K, Sinjo H, Murakami K, Okabe N. Evaluating radiation dose to the heart and the left anterior descending (LAD) coronary artery with left whole-breast radiation therapy to japanese women. Int J Radiat Oncol Biol Phys 2014 Sept 1; 90(1):261-62.

http://dx.doi.org/10.1016/j.ijrobp.2014.05.908

11. Darby SC, McGale P, Taylor CW, Peto R. Long-term mortality from heart disease and lung cancer after radiotherapy for early breast cancer: prospective cohort study of about 300000 woman in US SEER cancer registries. Lancet Oncol 2005;6:557-65. http://dx.doi.org/10.1016/S1470-2045(05)70251-5

12. Taylor CW1, Wang Z2, Macaulay E3, Jagsi R4, Duane F2, Darby SC2. 3. Exposure of the heart in breast cancer radiation therapy: a systematic review of heart doses published during 2003 to 2013. Int J Radiat Oncol Biol Phys 2015 Nov 15;93(4):845-53.

http://dx.doi.org/10.1016/j.ijrobp.2015.07.2292

13. Taylor CW, Nisbet A, McGale P, Goldman U, Darby SC, Hall $\mathrm{P}$, et al. Cardiac doses from Swedish breast cancer radiotherapy since the 1950s. Radiother Oncol 2009;90:127-35. http://dx.doi.org/10.1016/j.radonc.2008.09.029 


\section{KAIRĖS KRŪTIES SPINDULINĖ TERAPIJA: \\ DOZĖS ŠIRDŽIAI IR KAIRIOSIOS VAINIKINĖS ARTERIJOS PRIEKINEI TARPSKILVELINEI ŠAKAI VERTINIMAS}

A. Plieskiené, D. Burdulis

Raktažodžiai: kairès krūties spindulinè terapija, kritiniai organai.

Santrauka

Kairès krūties spindulinė terapija didina širdies ligų riziką. Nuo individualios pacientės anatomijos priklauso kiek priekinès širdies sienos ir kairiosios vainikinès arterijos priekinès tarpskilvelinès šakos spindulinès terapijos metu patenka ị švitinimo lauką.

Šio tyrimo tikslas buvo ịvertinti dozes kritiniams organams skiriant spindulinę terapiją kairès krūties věžio gydymui bei pateikti rekomendacijas kritinių organų apibrèžimui ir dozès vertinimui.

Išanalizuoti 32 atsitiktinai atrinkti kairès krūties spindulinio gydymo planai. Nors pagal vidutines dozes kritiniams organams planai buvo ịvertinti tinkamais, penktadaliui pacienčių skyrèsi dozès visai kairiosios vainikinès arterijos priekinei tarpskilvelinei šakai ir jos lankui.

Tyrimo rezultatai parodè, kad spindulinès terapijos plane vertinant vien tik vidutinę dozę širdžiai gali būti neteisingai įvertinta dozè kairiosios vainikinės arterijos priekinei tarpskilvelinei šakai. Tyrimo rezultatai taip pat atskleidè, kad dozes reikia vertinti širdžiai ir visai kairiosios vainikinès arterijos priekinei tarpskilvelinei šakai, ne vien tik jos lankui. Tai nulems mažesnę koronarinès širdies ligos riziką pacientėms, gydytoms spinduline terapija dèl kairès krūties vėžio.

Adresas susirašinèti: plieskiene@kul.lt

Gauta 2016-11-03 